\title{
Design of a Naphtha Preheater for Hydrodesulphurization (HDS) Unit of Petroleum Naphtha with given feed rate of 3500 Barrels Per Day (BPD)
}

\author{
Debajyoti Bose
}

\author{
University of Petroleum \& Energy Studies, College of Engineering Studies, \\ P.O. Bidholi via- Prem Nagar, Dehradun 248007, India \\ E-mail address: debajyoti1024@gmail.com
}

Keywords: furnace; heating; naphtha; hydrocarbon; heater

\begin{abstract}
Oil refining and petrochemical manufacture involves extensive heating of hydrocarbon and other fluids. Depending on the temperature required, this heating is achieved either by steam or direct heating. In the latter case, the fluid under pressure is contained in tubes which are heated from the outside by direct exposure to flames. These heaters commonly take two forms, cylindrical heaters with one central burner, or a ring of burners in the base and the long rectangular type with many burners in a row along the floor, the latter are generally known as cabin heaters. This paper shows the design of one such furnace.
\end{abstract}

\section{INTRODUCTION}

Petrochemical heaters are significantly different from boilers, with fewer larger tubes. With petrochemical heaters, it is very important that the heat transfer to the tubes is carefully controlled. If the heat transfer is too low, output is lost but if too high, local 'hot spots' are created. This is especially dangerous with hydrocarbon fluids because hot spots lead to carbon formation on the inside of the tube reducing the heat transfer to the fluid. However, the heat is still being transferred to the outer surface of the tube which overheats and will eventually fail, leaking hydrocarbon into the firebox. This is highly dangerous and will, at best, lead to destruction of the heater but at worst explosion and fire that may cause multiple casualties and destroy the entire plant.

In the past petrochemical heaters have been notoriously inefficient, using natural draft burners with high excess air, high flue gas temperatures and no heat recovery. The significance of these issues is considered later in the book. Such heaters rarely transferred more than $50 \%$ of the energy in the fuel to the fluid. Modern heaters utilize convective preheating of the liquid and heat recovery from the flue gas to preheat the combustion air, together with forced draft burners operating at controlled excess air and achieve much higher efficiencies.

One of the most common causes of poor oil burner performance is too high an oil viscosity at the burner caused by inadequate heating of the oil. Owing to the tendency of heavy fuel oil to solidify when cold, great care has to be taken with the design of oil fuel handling systems to minimize 'dead legs'. Since the lighter 'white' oil products have a higher value than black fuel oils, refineries increasingly manufacture more light products, leading to heavier and heavier black fuels containing increasing quantities of asphaltenes. These augmented refining processes involve 'cracking' the oil and produces black oils which have different characteristics from the former residual oils. These cracked fuels vary in character, depending on the source of crude and the refining process and are not necessarily compatible with each other. Under some circumstances, fuel oils from different sources can form 'gels' in tanks and fuel handling systems with disastrous results. 

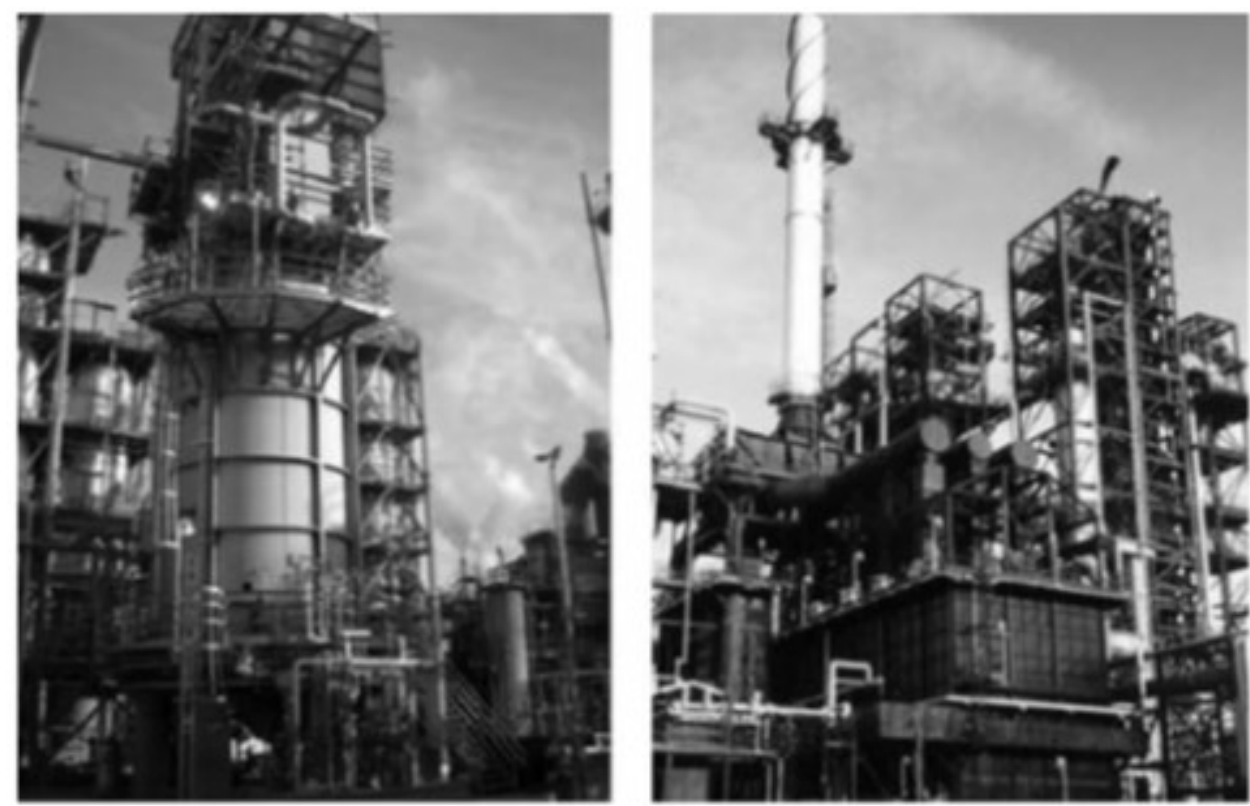

Figure 1: Two types of refinery heater showing a cylindrical heater (left) and a cabin heater (photos provided courtesy of Born Heaters, Canada, an Onquest Company)

Proposed fuels should therefore always be tested for compatibility with the existing fuel before purchase. Used lubricating oil is also occasionally available for use as a furnace fuel. Providing excess water is removed and the oil is filtered to minimize the presence of particulates, it burns satisfactorily. Similarly to heavy fuel oil it may need heating, typically to approximately $70^{\circ}$ $\mathrm{C}$ to ensure that the viscosity is suitable for atomization $(15-25 \mathrm{cSt})$.

Owing to the variability of this fuel, tests may be required to determine the correct temperature for each batch. Waste oils typically contain wear products from bearings such as lead and other heavy metals, so care needs to be exercised to ensure that these do not contaminate the product or cause excessive emissions of these pollutants. This normally means that these fuels may only be used in furnaces where suitable flue gas cleaning equipment is installed.

Comparison of the calculated data indicates that a cylindrical furnace is more thermally efficient than a rectangular design. However, the firing density is a factor of 2-3 times higher in a cylindrical furnace, with the same implications for the burner design as discussed in the previous section on the slab heating furnace. The results indicate that the height: length or height: diameter aspect ratios studied (8:1 to 2:1) are not very significant with respect to thermal performance.

The critical factor in the design of this type of furnace is to avoid locally high heat fluxes. This implies that the burner(s) need to be disposed inside the furnace to give a controlled combustion pattern. 


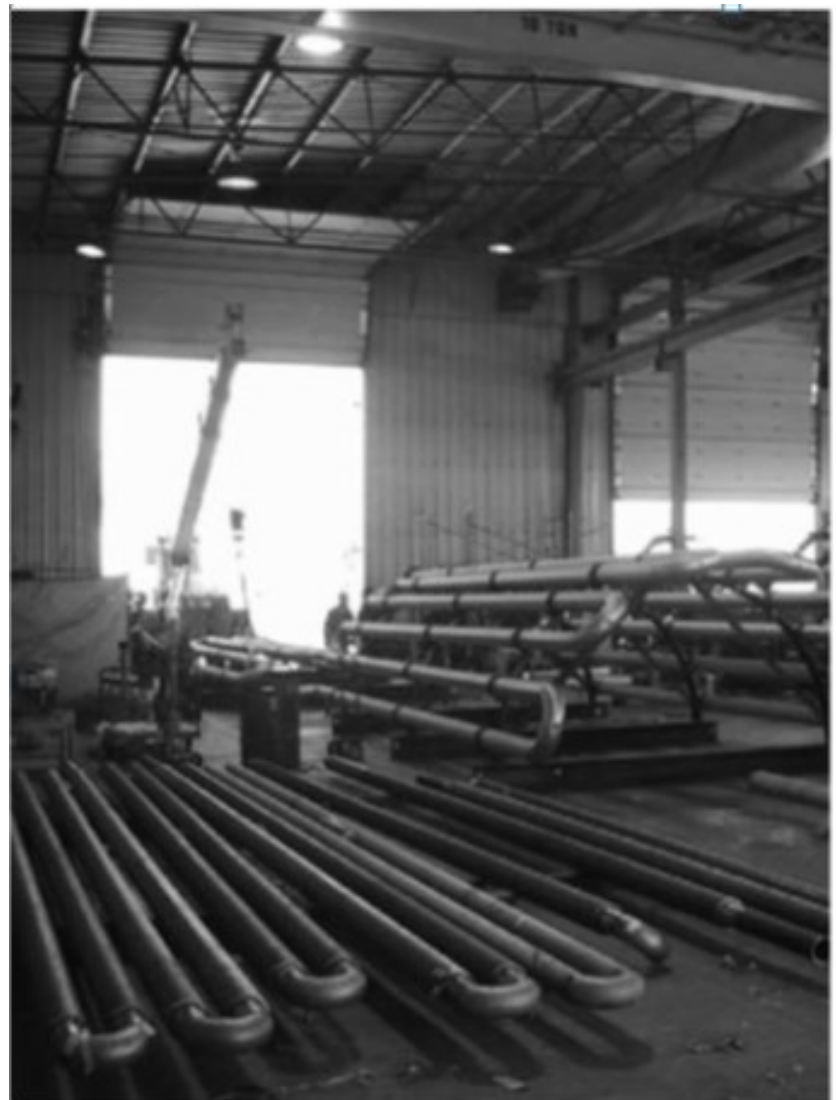

Figure 2: Heat transfer coils for refinery heaters showing a coil for cabin heater (foreground) and cylindrical heater in the background (photos provided courtesy of Born Heaters, Canada, an Onquest Company)

Table 1: Well-stirred furnace analysis of rectangular oil heating furnace designs

\begin{tabular}{|c|c|c|c|c|}
\hline Oil velocity in pipe $\mathrm{m} / \mathrm{s}$ & $v$ & 0.91 & 0.91 & 0.91 \\
\hline Pipe length in furnace $(v \cdot \tau \cdot 60) \mathrm{m}$ & $t_{t}$ & 245.7 & 245.7 & 245.7 \\
\hline Furnace height m & $h$ & 8 & 6 & 4 \\
\hline Number of tubes (integer of $l_{t} / h$ ) & $N$ & 31 & 41 & 62 \\
\hline Tube spacing between centres $\mathrm{m}$ & $p$ & 0.1 & 0.1 & 0.1 \\
\hline Furnace diameter $((N \cdot p / \pi)+p) m$ & $d_{f}$ & 1.09 & $1.4 \mid$ & 2.07 \\
\hline Refractory area $\mathrm{m}^{2}$ & $A_{r}$ & 28.24 & 28.04 & 29.43 \\
\hline Openings area $\mathrm{m}^{2}$ & $A_{0}$ & 0 & 0 & 0 \\
\hline Furnace volume $\mathrm{m}^{3}$ & $v$ & 7.42 & 9.30 & 13.51 \\
\hline \multicolumn{5}{|l|}{ Well-stirred furnace model results } \\
\hline Fuel rate $\mathrm{kg} / \mathrm{s}$ & $m_{f}$ & 0.0352 & 0.0352 & 0.0352 \\
\hline $\begin{array}{l}\text { Mass of combustion gases } \\
\left(m_{f}(I+S A R \cdot(I+X S / 100))\right) \mathrm{kg} / \mathrm{s}\end{array}$ & $m$ & 0.6428 & 0.6428 & 0.6428 \\
\hline Thermal input $\left(m_{f} \cdot C_{v}\right) \mathrm{kW}$ & $H_{f}$ & 1786 & 1786 & 1786 \\
\hline Dimensionless firing density & $D^{\prime}$ & 0.13 & 0.13 & 0.13 \\
\hline Dimensionless efficiency & $Q^{\prime}$ & 61.22 & 61.2 & 61.35 \\
\hline Heat losses kW & & 75.03 & 74.53 & 78.04 \\
\hline Thermal efficiency & $\eta$ & 67.9 & 67.9 & 67.8 \\
\hline Average furnace gas temperature ${ }^{\circ} \mathrm{C}$ & $T_{g}$ & 1068 & 1068 & 1066 \\
\hline Flue gas temperature ${ }^{\circ} \mathrm{C}$ & & 551 & 552 & 544 \\
\hline Average heat flux $\mathrm{kW} / \mathrm{m}^{2}$ & & 27.61 & 27.61 & 27.66 \\
\hline Firing density $\mathrm{kW} / \mathrm{m}^{3}$ & & 240.7 & 192.0 & 132.2 \\
\hline
\end{tabular}


Table 2: Well-stirred furnace analysis of cylindrical oil heating furnace designs

\begin{tabular}{|c|c|c|c|c|}
\hline Oil velocity in pipe $\mathrm{m} / \mathrm{s}$ & $v$ & 0.91 & 0.91 & 0.91 \\
\hline Pipe length in furnace $(v \cdot \tau \cdot 60) \mathrm{m}$ & $I_{t}$ & 245.7 & 245.7 & 245.7 \\
\hline Furnace height $\mathrm{m}$ & $h$ & 8 & 6 & 4 \\
\hline Number of tubes (integer of $l_{t} / h$ ) & $N$ & 31 & 41 & 62 \\
\hline Tube spacing between centres $\mathrm{m}$ & $p$ & 0.1 & 0.1 & 0.1 \\
\hline Furnace diameter $((N \cdot p / \pi)+p) m$ & $d_{f}$ & 1.09 & 1.41 & 2.07 \\
\hline Refractory area $\mathrm{m}^{2}$ & $A_{r}$ & 28.24 & 28.04 & 29.43 \\
\hline Openings area $\mathrm{m}^{2}$ & $A_{0}$ & 0 & 0 & 0 \\
\hline Furnace volume $\mathrm{m}^{3}$ & $V$ & 7.42 & 9.30 & 13.51 \\
\hline \multicolumn{5}{|l|}{ Well-stirred furnace model results } \\
\hline Fuel rate $\mathrm{kg} / \mathrm{s}$ & $m_{f}$ & 0.0352 & 0.0352 & 0.0352 \\
\hline $\begin{array}{l}\text { Mass of combustion gases } \\
\qquad\left(m_{f}(I+S A R \cdot(I+X S / I 00))\right) \cdot k g / s\end{array}$ & $m$ & 0.6428 & 0.6428 & 0.6428 \\
\hline Thermal input $\left(m_{f} \cdot C_{v}\right) \mathrm{kW}$ & $H_{f}$ & 1786 & 1786 & 1786 \\
\hline Dimensionless firing density & $D^{\prime}$ & 0.13 & 0.13 & 0.13 \\
\hline Dimensionless efficiency & $Q^{\prime}$ & 61.22 & 61.2 & 61.35 \\
\hline Heat losses kW & & 75.03 & 74.53 & 78.04 \\
\hline Thermal efficiency & $\eta$ & 67.9 & 67.9 & 67.8 \\
\hline Average furnace gas temperature ${ }^{\circ} \mathrm{C}$ & $T_{g}$ & 1068 & 1068 & 1066 \\
\hline Flue gas temperature ${ }^{\circ} \mathrm{C}$ & & 551 & 552 & 544 \\
\hline Average heat flux $\mathrm{kW} / \mathrm{m}^{2}$ & & 27.61 & 27.61 & 27.66 \\
\hline Firing density $\mathrm{kW} / \mathrm{m}^{3}$ & & 240.7 & 192.0 & 132.2 \\
\hline
\end{tabular}

\section{METHOD}

For the design the following values were given:

Mass flow rate of Naphtha $(\mathrm{m})=16695 \mathrm{~kg} / \mathrm{hr}(3500 \mathrm{BPD})$

Specific gravity $=0.69$

Specific heat $=0.56 \mathrm{~kJ} / \mathrm{kg} \mathrm{K}$

Let inlet temperature to heater $=211^{\mathrm{O}} \mathrm{C}$

Outlet temperature from heater $=350{ }^{\circ} \mathrm{C}$

Using energy balance and material balance principles the following were calculated or estimated:

1. Heat required to raise the temperature of feed from $211{ }^{\mathrm{O}} \mathrm{C}$ to $252{ }^{\mathrm{O}} \mathrm{C}$

2. Design of radiation section

3. Actual volume of radiation section

4. Arrangement of tubes

5. Design of convective section

6. Determination of flue gas velocity

7. Determination of convection coefficient

8. Calculation of area of convective heat transfer

9. Determination of number of tubes

Suitable assumptions were made wherever necessary. 


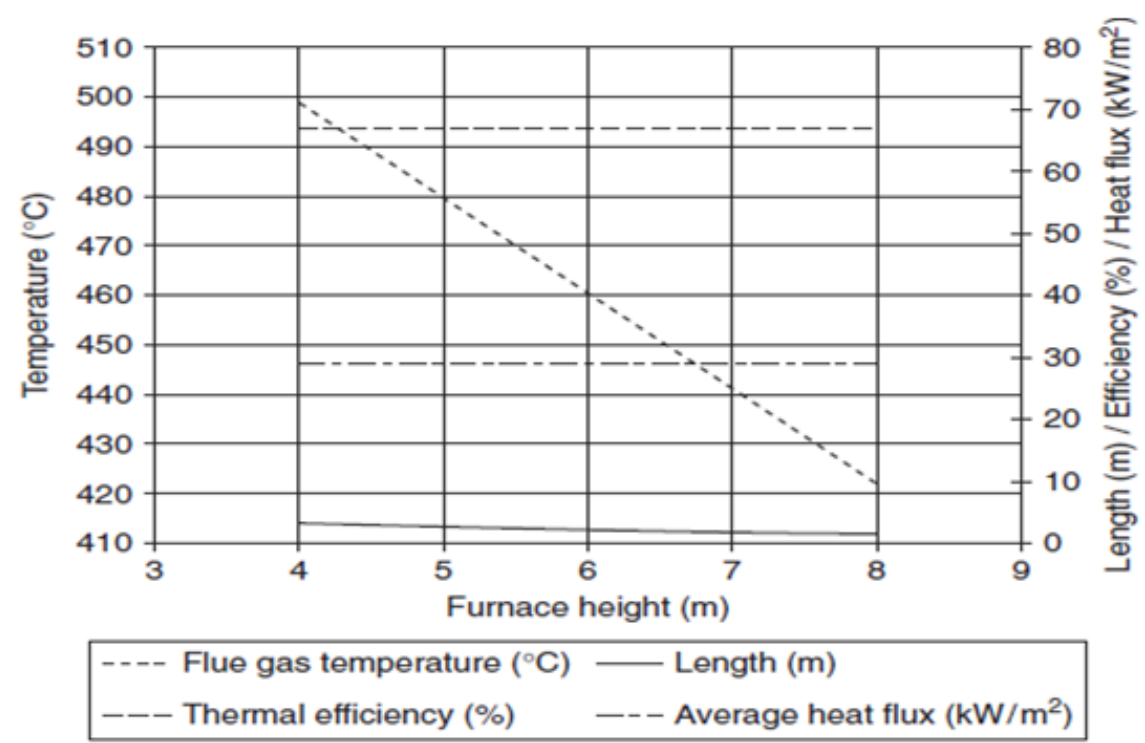

Figure 3: Effect of furnace height on principal parameters in the design of a rectangular oil heating furnace

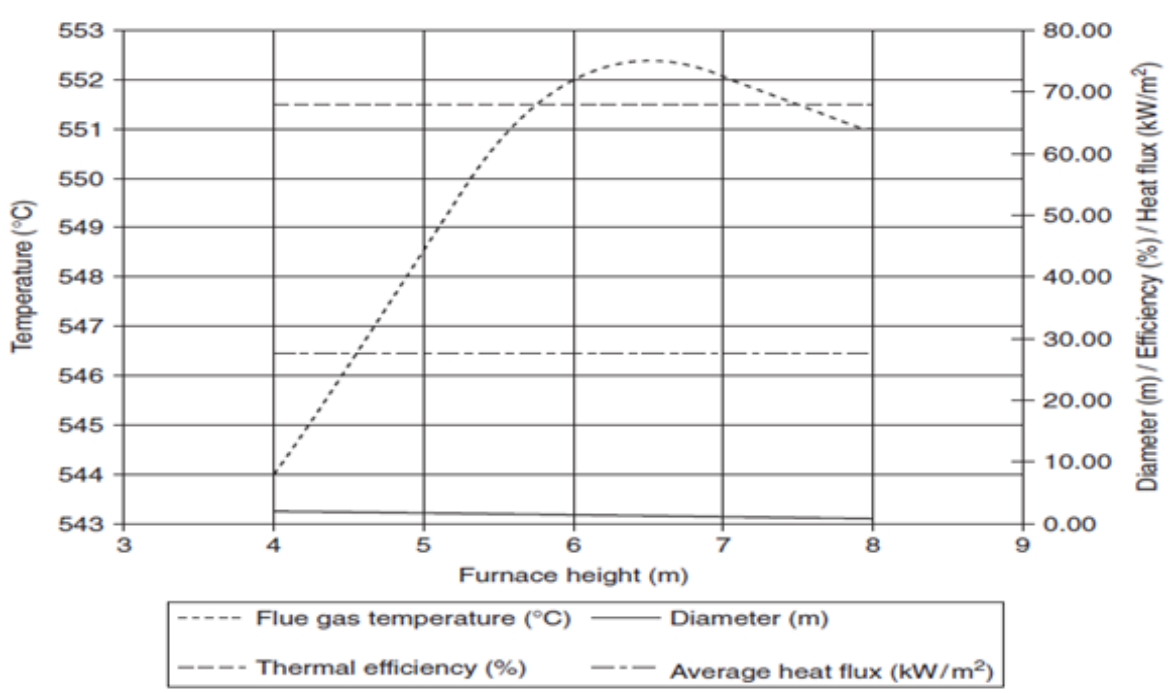

Figure 4: Effect of furnace height on principal parameters in the design of a cylindrical oil heating furnace

\section{RESULT}

The following results were obtained based on the calculations.

For the Radiation section:

\begin{tabular}{|l|l|}
\hline PARAMETERS & VALUES \\
\hline Total Heat Produced & $414.52 \times 10^{5} \mathrm{KJ}$ (Kilo Joules) \\
\hline Total Heat by Fuel & $48913360 \mathrm{~kJ}$ (Kilo Joules) \\
\hline Amount of Fuel Required & $759 \mathrm{Kg}$ (Kilo Grams) \\
\hline Approximate volume of the radiation section & $345 \mathrm{~m}^{3}$ (cubic meters) \\
\hline $\begin{array}{l}\text { Number of tubes required in the radiation } \\
\text { section of the Furnace }\end{array}$ & 59 \\
\hline Number of Tubes on side wall of Furnace & 16 \\
\hline Number of Tubes on the top wall of Furnace & 27 \\
\hline Total width of the Furnace & 6.1 meters \\
\hline Length of Tube & 10 meters \\
\hline Volume of the Furnace & $157.5 \mathrm{~m}^{3}$ (cubic meters) \\
\hline
\end{tabular}


For the Convective Section:

\begin{tabular}{|l|l|}
\hline PARAMETERS & VALUES \\
\hline Amount of fuel burnt & $760 \mathrm{Kg}$ (Kilo Grams) \\
\hline Amount of air burnt & $18975 \mathrm{Kg} /$ hour \\
\hline Total amount of flue gas & $19734 \mathrm{~kg} /$ hour \\
\hline Flue gas velocity & $0.274 \mathrm{~kg} / \mathrm{m}^{2} \mathrm{sec}$ \\
\hline Convection heat & $1243500 \mathrm{KJ}$ (Kilo Joules) \\
\hline $\begin{array}{l}\text { Logarithmic Mean Temperature Difference } \\
\text { (LMTD) }\end{array}$ & $337.5^{\circ} \mathrm{C}$ \\
\hline
\end{tabular}

Area of convective heat transfer $=645.051 \mathrm{~m}^{2}$

Number of tubes $=296.46 \cong 270$

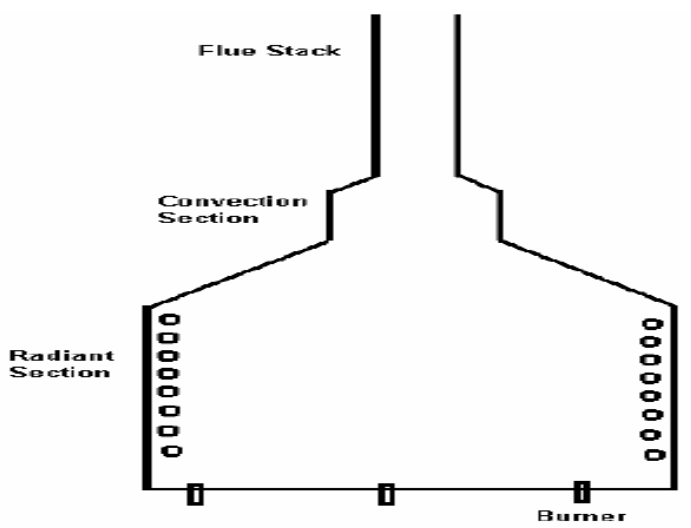

Figure 5: Outlines of the Burner

\section{DISCUSSIONS}

Furnaces have been used by humans for thousands of years and yet, beyond the basic chemical reactions and heat release calculations, engineers rarely have any formal training in relation to furnace design, combustion and their integration into industrial processes. It is therefore not surprising that the solution to issues of emissions, throughput and performance related problems have relied heavily on trial and error and experience. Within industry in general equipment would be more successful designed using the principals outlined in this paper rather than relying on correlations and scale up factors that have little, or no scientific basis to support them.

\section{Reference}

[1] Petroleum Refinery Engineering, W.L. Nelson, McGraw-Hill Book Company.

[2] API- Petroleum Refining- Technical Data Book, Sixth Edition, American Petroleum Institute.

[3] Petroleum Refinery Distillation, R.N. Watkins, Gulf Publishing Company.

[4] Handbook of Chemical Engineering Calculations, Third Edition, Nicholas P. Chopey, McGraw-Hill Handbooks.

[5] Heat Exchanger Design Handbook, T. Kuppan, Southern Railway Madras, Marcel Dekker Inc.

[6] Practical Thermal Design of Shell-and-Tube Heat Exchangers, R. Mukherjee, Begell House Inc.

[7] The Chemistry and Technology of Petroleum,4th Edition, James G. Speight, CRC Press.

[8] Petroleum Refining Separation Processes, Jean Pierre Wauquire, Technip.

[9] Sulfur Removal and Recovery from Industrial Processes, John B. Pfeiffer, American Chemical Society Library. 
[10] Thermal and Catalytic Process in Petroleum Refining, Robin Jenson.

[11] Applied Process Design \& Compressor design, Ernest E. Ludwig, Volume 1, Third edition.

[12] Applied Process Design \& Compressor design, Ernest E. Ludwig, Volume 2, Third edition.

[13] Applied Process Design \& Compressor design, Ernest E. Ludwig, Volume 3, Third edition.

[14]Chemical Process Equipment,2nd edition, James R. Couper, Elsevier, Butterwoth-Heinemann.

[15] Industrial and Process Furnaces, Principles, Design and Operation, Peter Mullinger, Elsevier, Butterworth-Heinemann.

[16]Refinery Process Modeling, First Edition, Gerald E. Kaes, The Athens Printing Company.

[17] Thermal and Catalytic Processes in Petroleum Refining, Serge Raseev, Marcel Dekker Inc.

[18]Petroleum Processing Handbook, John J. Mcketta, CRC Press.

[19]Process Heat Transfer, DQ Kern, McGraw-Hill Book Company.

[20]Coulson and Richardson, Chemical Engineering Volume 1, Sixth Edition.

[21]Coulson and Richardson, Chemical Engineering Volume 2, Sixth Edition.

[22] Coulson and Richardson, Chemical Engineering Volume6, Sixth Edition.

[23] Chemical Process Principles, O.A. Hougen and K.M. Watson. Second edition, CBS publishers $\&$ distributors.

[24]Perry's Chemical Engineering Hand Book, MGH.

[25] Reynolds, J.G. and Beret, S. 1989. Fuel Sci. Technol. Int. 7: 165.

[26] Scott, J.W. and Bridge, A.G. 1971. In Origin and Refining of Petroleum. H.G. McGrath and M.E. Charles, eds. Advances in Chemistry Series 103. American Chemical Society, Washington, DC, p. 113.

[27] Setti, L., Farinelli, P., Di Martino, S., Frassinetti, S., Lanzarini, G., and Pifferia, P.G. 1999. Appl.

[28] Microbiol. Biotechnol. 52: 111-117.

[29] Speight, J.G. 1986. Ann. Rev. Energy. 11: 253.

[30] Speight, J.G. and Moschopedis, S.E. 1979. Fuel Process. Technol. 2: 295.

[31] Stanislaus, A. and Cooper, B.H. 1994. Catal. Rev.-Sci. Eng. 36(1): 75.

[32] Suchanek, A.J. and Moore, A.S. 1986. Oil Gas J. 84(31): 36.

[33] Swain, E.J. 1991. Oil Gas J. 89(36): 59.

[34] Swain, E.J. 1993. Oil Gas J. 91(9): 62.

[35] Swain, E.J. 1997. Oil Gas J. 95(45): 79.

[36] Swain, E.J. 2000. Oil Gas J. March 13.

[37] Tanaka, H. 2004. Process for producing hydrofining catalyst. United States Patent 6,689,712. February 10.

[38] Topsøe, H. and Clausen, B.S. 1984. Catal. Rev. Sci. Eng. 26: 395.

[39] Van Hamme, J.D., Singh, A., and Ward, O.P. 2003. Microbiol. Mol. Biol. Rev. 67(4): 503-549. 